\title{
Multiple Cancer Sites
}

National Cancer Institute

\section{Source}

National Cancer Institute. Multiple Cancer Sites. NCI Thesaurus. Code C13419.

More than one cancer site. 